\title{
MOLECULAR CHARACTERIZATION OF ENTEROINVASIVE ESCHERICHIA COLI IPA GENES BY PCR- RFLP ANALYSIS
}

\author{
Adriana Gibotti ${ }^{1}$; Tânia L. Tanaka ${ }^{2}$; Valéria R. Oliveira ${ }^{1}$; Carla R. Taddei ${ }^{1}$; Marina B. Martinez ${ }^{12 *}$ \\ ${ }^{1}$ Departamento de Microbiologia, Instituto de Ciências Biomédicas, Universidade de São Paulo, São Paulo, SP, Brasil; \\ ${ }^{2}$ Departamento de Análises Clínicas e Toxicológicas Faculdade de Ciências Farmacêuticas, Universidade de São Paulo, São \\ Paulo, SP, Brasil.
}

Submitted: December 04, 2003; Returned to authors: March 05, 2004; Approved: May 20, 2004.

\begin{abstract}
In this study, polymorphism in ipa genes was found in five out of nine EIEC serotypes studied. When SalI and HindII were used in RFLP-PCR assays many EIEC serotypes showed polymorphism in ipaB and ipaD. On the other hand, no polymorphism was observed in ipa $\mathrm{A}$ and $i p a \mathrm{C}$ in these strains. The polymorphism present in EIEC strains is serotype-dependent, since restriction patterns were conserved amongst strains belonging to the same serotype. When IpaB deduced amino acid sequences of S. flexneri M90T and FBC12413 were compared, ten amino acids changes could be observed mainly in the amino-terminal region. The deduced EIEC IpaD amino-acid sequence presented 91\% similarity with the Shigella strain. In this case, amino acid changes were spread out through the whole structure, except in the carboxyl-terminal region.
\end{abstract}

Key words: ipa, enteroinvasive Escherichia coli, polymorphism, PCR-RFLP

\section{INTRODUCTION}

Escherichia coli plays an important role in maintaining intestinal physiology. However, there are pathogenic strains that cause distinct syndromes of diarrheal disease.

During the 60's in XX century, it was found that E. coli strains isolated from patients with dysentery were also able to cause experimental keratoconjunctivitis in guinea pigs and caused a Shigella-like illness in humans, both children and adults $(17,19,22)$. These $E$. coli strains are known as enteroinvasive $E$. coli (EIEC) and belong to the following O serotypes: O28ac:NM; O29:NM; O112ac:NM; O121:NM; O124:NM; O124:H30; O136:NM; O143:NM; O144:NM; O152:NM; O164:NM;O167:NM (13). Like Shigella spp., EIEC strains are frequently lactose negative, consistently lysine decarboxylase negative, and nonmotile, except the serotype O124:H30.

The role played by EIEC in endemic diarrheal disease has not been investigated extensively. However, some studies have indicated that EIEC can be isolated with a relatively high frequency depending on the population being investigated $(1,2,9,14,16,20,21)$. In the city of Sao Paulo, in Brazil, EIEC has been found in $5-7 \%$ of children living in medium-income families and in $20 \%$ of children who live in a slum, in the outskirts of the city. Both groups studied were composed of children older than 2 years presenting acute diarrhea (21). A similar frequency has been reported by Echeverria et al. (2) in Bangkok. Outbreaks of food-borne infections due to EIEC have also been reported elsewhere (13).

Both EIEC and Shigella spp. strains cause bacillary dysentery in humans by invading and multiplying within epithelial cells of the colonic mucosa. This remarkable tropism results in an intense inflammatory response characterized by abscesses and ulcerations that damage the integrity of the epithelial cell lining of the colon, producing the pathognomonic symptoms of dysentery (5). The entry of Shigella and EIEC bacteria into susceptible host target cells requires the coordinated expression of numerous genes that are activated in response to signals of the microenvironment. The entire

*Corresponding author. Mailing address: Av. Prof. Lineu Prestes, 580 - bl 17, USP. 05508-900, São Paulo, SP, Brasil. Tel.: (+5511) 30913636. Fax: (+5511) 38132197. E-mail: mbmartin@usp.br 
repertoire of genes required for entry into host cells is clustered in a $220 \mathrm{~kb}$ virulence-associated invasion plasmid present both in Shigella and EIEC strains $(7,18)$. However, most of the genetic and structure-function studies regarding the biological interaction of these invasive bacteria with eukaryotic cells have been centered on Shigella rather than EIEC.

Expression of several plasmid-encoded proteins is required for the complete virulence phenotype of Shigella ssp. Ipa (invasion plasmid antigen) proteins A (71kDa), B (62 kDa), C $(43 \mathrm{kDa})$ and $\mathrm{D}(38 \mathrm{kDa})$ are encoded in the ipa operon (ipaA; $i p a \mathrm{~B}$; ipa $\mathrm{C}$; ipa $\mathrm{D})(15)$. Mutants of ipa $\mathrm{B}$, ipa $\mathrm{C}$, and ipa $\mathrm{D}$ were unable to induce actin polymerization at the site of attachment of bacteria to the cell membrane and were therefore unable to enter $(8,12)$. Moreover, when internalized by macrophages, ipa mutants remain trapped in the phagosome and are not cytotoxic. This suggests that Ipa proteins are also involved in lysis of the endosome membrane upon entry to epithelial cells (25).

The cellular biology and genetics of entry have been investigated using mainly S. flexneri. However, most conclusions derived from these studies probably apply to other Shigella species, as well as to EIEC. Nevertheless, the precise pathogenesis of EIEC has yet to be elucidated.

Due to the important role that the ipa cluster plays in the entry of enteroinvasive bacteria to epithelial cells and to the lack of data available in literature regarding EIEC ipa genes, the aim of this work was to characterize EIEC ipa genes among several EIEC serotypes.

\section{MATERIALS AND METHODS}

\section{Bacterial strains}

Forty-two EIEC strains of different serotypes (Table 1) were isolated from the diarrheic stool of children, during the period running from 1964 to 1988 , being 1 sample from Chile, 1 from South Vietnam, 2 from Japan and 38 from Brazil. These strains were Sèreny test positive when they were isolated, and they were previously identified by biochemical and serological methods (11). Only those clones that were positive for Congo red binding were used. S. flexneri M90T and E. coli DH5 $\alpha$ were used as positive and negative controls, respectively.

\section{Amplification of ipa $\mathrm{A}$, ipaB, ipaC and ipaD genes}

The ipa genes of EIEC strains were amplified by PCR with primers designed based on the known sequences of the $\mathrm{NH}_{2-}$ terminal and C-terminal regions of ipa $\mathrm{A}, i p a \mathrm{~B}$, ip $a \mathrm{C}$ and $i p a \mathrm{D}$ of $S$. flexneri (M90T) (24). The primer sequences are listed in Table 2.

\section{DNA cloning and sequencing}

In order to proceed to the sequencing of the ipa $\mathrm{B}$ gene of the FBC124-13 O124:NM) and FBC167-8 (O168:NM) EIEC strains, the $\mathrm{PCR}$ products generated with primers ipaB-F and ipaB-R (Table 2) were cloned into a pUC18 cloning vector according to the manufacturer's instructions. Sequence analysis was carried out using two of the three recombinant plasmids obtained. In order to sequence the ipaD gene of EIEC strains FBC124-13 and FBC144-7 (O144:NM), three different products generated with primer set ipaD-F and ipaD-R (Table 2) were directly sequenced. An ABI PRISM 377 DNA Sequencer (Perkin-Elmer, Foster City, CA-USA) and a BigDye Terminator Cycle Sequencing Ready Reaction (Applied Biosystems Foster City, CA-USA) were used according to the manufacturer's recommendations.

\section{Polymorphism of ipa genes by endonuclease restriction}

The amplified fragments of the ipa $\mathrm{A}, i p a \mathrm{~B}, i p a \mathrm{C}$ and $i p a \mathrm{D}$ genes of EIEC and M90T strains were analyzed by RFLP. Restriction enzymes were chosen according to the nucleotide sequences described for S. flexneri (24), by consulting the URL: http://www.firstmarket.com/firstmarket/cutter. The restriction enzymes and the expected fragments are listed in Table 2. The fragment digestions were performed according to manufacturer's instructions (Invitrogen, Carlsbad, CA-USA).

\section{RESULTS}

PCR-RFLP analysis of the EIEC ipa genes, using different restriction endonuclease enzymes (Table 2), showed three distinct groups among EIEC serotypes: A, B, and C (Table 1). The first group (A) maintained the same restriction profile than that of S. flexneri M90T (serotypes O28:NM, O144:NM, O164:NM, and O167:NM) for all ipa genes. In group B, RFLP analysis demonstrated the occurrence of polymorphisms of the

Table 1. Strains tested and ipa RFLP polymorphism.

\begin{tabular}{lcccc}
\hline Serotypes & \begin{tabular}{c}
$\mathrm{N}^{\text {o }} \begin{array}{c}\text { of isolates } \\
\text { tested }\end{array}$ \\
\cline { 3 - 5 }
\end{tabular} & \multicolumn{3}{c}{$\begin{array}{c}\mathrm{N}^{\mathrm{o}} \text { of isolates with the } \\
\text { following RFLP polymorphism }\end{array}$} \\
\cline { 3 - 5 } O28ac:NM & 4 & 4 & & $\mathrm{C}$ \\
O29:NM & 5 & & 5 & \\
O124:NM & 6 & & 6 & \\
O136:NM & 5 & & 5 & 4 \\
O143:NM & 4 & & & \\
O144:NM & 5 & 5 & & \\
O152:NM & 4 & & 3 & \\
O164:NM & 4 & 4 & & \\
O167:NM & 5 & 5 & & \\
\hline Total & 42 & 18 & 19 & 4 \\
\hline
\end{tabular}

A - no occurrence of polymorphism;

$\mathrm{B}$ - occurrence of polymorphisms in the ipa $\mathrm{B}$ and ipa $\mathrm{D}$ genes;

$\mathrm{C}$ - occurrence of polymorphism in the ipaD;

* - all strains were Congo red test positive. 
Table 2. Primers and restriction endonuclease enzymes used and size of restriction fragments of PCR products obtained from EIEC strains.

\begin{tabular}{|c|c|c|c|c|c|}
\hline Gene & Oligonucleotide sequence $5^{\prime}-3^{\prime}$ & $\begin{array}{c}\text { Size of } \\
\text { PCR products } \\
\text { expected }^{4}(\mathrm{bp})\end{array}$ & $\begin{array}{l}\text { Restriction } \\
\text { endonuclea } \\
\text { enzymes }\end{array}$ & $\begin{array}{c}\text { Size of restriction } \\
\text { fragments } \\
\text { expected }^{5}(b p)\end{array}$ & $\begin{array}{c}\text { Size of restriction } \\
\text { obtained from } \\
\text { EIECstrains } \\
\text { (bp, approximately) }\end{array}$ \\
\hline ipaA & $\begin{array}{l}\text { ipaA-F ATGCATAATGTAAATAATACT } \\
\text { ipaA-R ATTGATATTCTTTAATACTTT }\end{array}$ & 1900 & $\begin{array}{c}H a e I I I \\
B g l I I\end{array}$ & $\begin{array}{l}440,650 \text { and } 800 \\
680 \text { and } 1,200\end{array}$ & $\begin{array}{l}440,650 \text { and } 800 \\
680 \text { and } 1,200\end{array}$ \\
\hline ipa $\mathrm{B}$ & $\begin{array}{l}\text { ipaB-F'AAGCTT-TGCACAACGTDAGCACCACCACCACC } \\
\text { ipaB-R }{ }^{2} \text { CCGATATC-TATTTGTATCAAGCAGTAGTTTGTTG }\end{array}$ & 1750 & $\begin{array}{l}\text { PvuII } \\
\text { DraI } \\
\text { SalI }\end{array}$ & $\begin{array}{c}750 \text { and } 1,000 \\
270,700 \text { and } 800 \\
200,400 \text { and } 1,150\end{array}$ & $\begin{array}{c}750 \text { and } 1,000 \\
270,700 \text { and } 800 \\
600 \text { and } 1,150\end{array}$ \\
\hline ipaC & $\begin{array}{l}\text { ipaC-F }{ }^{3} \text { CCCCCGGG-GGAAATTCAAAACACAAAACCAACC } \\
\text { ipaC-R }{ }^{1} \text { CCAAGCTT-CGCACGAATATTACCCGCAATCTGACT }\end{array}$ & 1100 & $\begin{array}{c}B g l \mathrm{I} \\
P v u \mathrm{II}\end{array}$ & $\begin{array}{l}250 \text { and } 850 \\
430 \text { and } 680\end{array}$ & $\begin{array}{l}250 \text { and } 850 \\
430 \text { and } 680\end{array}$ \\
\hline ipa $\mathrm{D}$ & $\begin{array}{l}\text { ATGAATATAACAACTCTGACT } \\
\text { ATGGACAAAAAGTTTATCTGT }\end{array}$ & 1000 & $\begin{array}{c}\text { EcoRV } \\
\text { HindIII } \\
\text { HindII }\end{array}$ & $\begin{array}{c}400 \text { and } 600 \\
230 \text { and } 770 \\
200,380 \text { and } 420\end{array}$ & $\begin{array}{l}400 \text { and } 600 \\
230 \text { and } 770 \\
200 \text { and } 800\end{array}$ \\
\hline
\end{tabular}

1- HindIII endonuclease restriction site; 2- EcoRV endonuclease restriction site; 3- SmaI endonuclease restriction site; 4- Venkatesan, et al., 2001; 5- http://www.firstmarket.com/firstmarket/cutter.

$i p a \mathrm{~B}$ and ipa $\mathrm{D}$ genes in all strains belonging to the $\mathrm{O} 29: \mathrm{NM}$, O124:NM; 0136:NM and O152:NM serotypes when SalI (with generated fragments of $1,150 \mathrm{bp}$ and $600 \mathrm{bp}$ ) and HindII (with generated fragments $200 \mathrm{bp}$ and $800 \mathrm{bp}$ ) were used, respectively (Figs. 1a,1b). The polymorphisms of ipa $\mathrm{B}$ and ipa $\mathrm{D}$ were conserved in these serotypes, except for one O152:NM serotype strain (FBC152-26), which showed polymorphism of IpaB, only. The third group $(\mathrm{C})$ is represented by all strains belonging to serotype O143:NM, which showed polymorphism of ipaD, only. No serotypes showed polymorphism of ipaA or ipaC. The polymorphisms found in these EIEC serotypes appear to be conserved since all PCR fragments presented the same profile for those restriction endonuclease enzymes used.

Nucleotide sequences of ipa $\mathrm{B}$ and ipa $\mathrm{D}$ of EIEC proved to be highly similar to that of the Shigella ipa genes. The deduced amino acid sequences of IpaB and IpaD are shown in Figs. 2 and 3, respectively. The change at codon position 1,496 (AㄷA $\rightarrow$ AAA) resulted in a change in the deduced amino acid residue 520 position $(\mathrm{T} \rightarrow \mathrm{K})$, leading to the loss of one restriction site in IpaB (Fig. 2). For IpaD, the base change at position 511
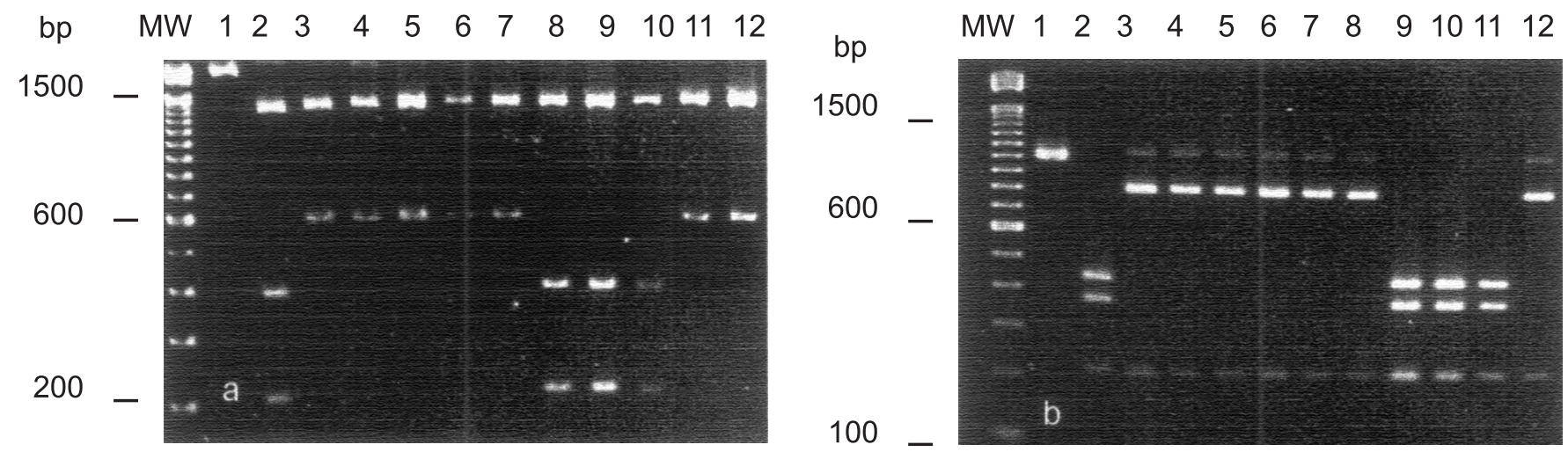

Figure 1. RFLP-PCR of the ipaB genes digested with SalI (a) and ipaD with HindII (b) of different serotypes of EIEC strains. Lane MW, 100 bp DNA ladder (Gibco BRL); lane 1, PCR fragments of ipaB (a) and ipaD (b); lane 2, FBC28-1(O28:NM); lane 3, FBC297 (O29:NM); lane 4, FBC124-13 (O124:NM); lane 5, FBC124-33 (O124:NM); lane 6, FBC136-1 (O136:NM); lane 7, FBC136-37 (O136:NM); lane 8 FBC143-14(O143:NM); lane 9, FBC144-7 (O144:NM); lane 10, M90T; lane 11, FBC152-26(O152:NM); lane 12, FBC152-31 (O152:NM). 
(AA $\underline{\mathrm{C}} \rightarrow \mathrm{AA} \underline{\mathrm{A}}$ ) abolished one of the HindII sites, resulting in a change in the deduced amino acid residue 193 position $(\mathrm{N} \rightarrow \mathrm{K})$ (Fig. 3). These differences seemed to be conserved in the O29:NM, O124:NM; 0136:NM, and O152:NM serotypes, and for all O143:NM EIEC strains for IpaD.

The similarity between IpaB of the FBC124-13 EIEC strain and S. flexneri M90T was $97 \%$ and $41 \%$ with the SipB protein of
Salmonella enterica serovar Typhimurium. When IpaB deduced amino acid sequences of S. flexneri M90T and FBC124-13 are compared, ten and seven different amino acids can be observed in the amino-terminal and carboxyl-terminal regions, respectively (Fig. 2). However, there is $100 \%$ identity between Shigella and EIEC in the hydrophobic region (amino acids 310-423), and 65\% between EIEC and Salmonella $(4,10)$.

\begin{tabular}{|c|c|c|}
\hline S.flexneri & 1 & MHNVSTTTTGFPLAKILT STELGDNTIQAANDAANKLFSLTIADLTANQNINTTNAHSTS \\
\hline EIEC 167-8 & 1 & 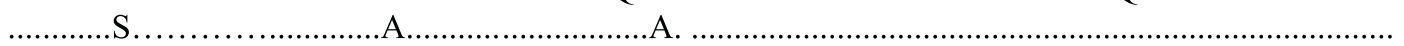 \\
\hline EIEC 124-13 & 1 & 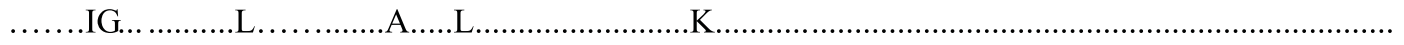 \\
\hline S.flexneri & 61 & NILIPELKAPKSLNASSQLTLLIGNLIQILG EKSLTALTNKITAWKSQQQARQQKNLEFS \\
\hline EIEC 167-8 & 59 & (1) \\
\hline EIEC 124-13 & 61 & \\
\hline S.flexneri & 121 & DKINTLLSETEGLTRDYEKQINKLKNADSKIKDLENKINQIQTRL SNLDPESPEKKKLSR \\
\hline EIEC 167-8 & 119 & (1) \\
\hline EIEC 124-13 & 121 & 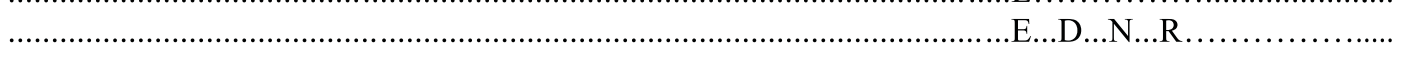 \\
\hline S.flexneri & 181 & EEIQLTIKKDAAVKDRTLIEQKTLSIHSKLTDKSMQLEKEIDSFSAFSNTASAEQLSTQQ \\
\hline EIEC $167-8$ & 179 & \\
\hline EIEC 124-13 & 181 & \\
\hline S.flexneri & 241 & KSLTGLASVTQLMATFIQLVGKNNEESLKNDLALFQSLQESRKTEMERKSDEYAAEVRKA \\
\hline EIEC 167-8 & 239 & \\
\hline EIEC 124-13 & 241 & \\
\hline S.flexneri & 301 & EELNRVMGCVGKILGALLTIVSVVAAAFSGGASLALAAVGLALMVTDAIVQAATGNSFME \\
\hline EIEC 167-8 & 299 & (1) \\
\hline EIEC 124-13 & 301 & 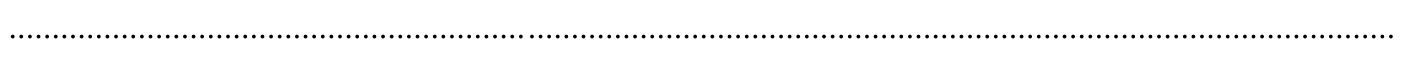 \\
\hline S.flexneri & 361 & QALNPIMKAVIEPLIKLLSDAFTKMLEGLGVDSKKAKMIGSILGAIAGALVLVAAVVLVA \\
\hline EIEC 167-8 & 359 & \\
\hline EIEC 124-13 & 361 & ......................... \\
\hline S.flexneri & 241 & TVGKQAAAKLAENIGKIIGKTLTDLIPKFLKNFSSQLDDLITNAVARLNKFLGAAGDEVI \\
\hline EIEC $167-8$ & 419 & (1) \\
\hline EIEC 124-13 & 421 & (1) \\
\hline S.flexneri & 481 & SKQIISTHLNQAVLLGESVNSATQAGGSVASAVFQNSASTNLADLTLSKYQVEQLSKYIS \\
\hline EIEC 167-8 & 479 & \\
\hline EIEC 124-13 & 481 & . \\
\hline S.flexneri & 541 & EAIEKFGQLQEVIADLLASM----.. \\
\hline EIEC 167-8 & 539 & \\
\hline EIEC 124-13 & 541 & ................ . \\
\hline
\end{tabular}

Figure 2. Alignment of ipaB amino acid sequence of the S. flexneri, S. dysenteriae and EIEC FBC167-8 (O167:NM) (without polymorphism) and FBC124-13 (O124:NM) (with polymorphism). The identical amino acids are indicated by dots. In the sample FBC124-13 occurred a mutation that abolished the SalI site and caused an amino acid change from Thr (T) $\rightarrow$ Lys (K) (underlined). 


\begin{tabular}{|c|c|c|}
\hline S.flexneri & 1 & MNITTLTNSISTSSFSPNNTNGSSTETVNSDIKTTTSSHPVSSLTMLNDTLHNIRTTNQA \\
\hline EIEC 144-7 & 1 & -"- \\
\hline EIEC 124-13 & 1 & 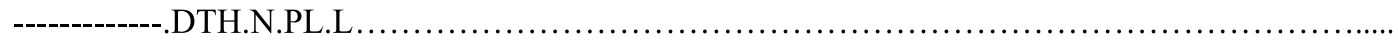 \\
\hline S.flexneri & 61 & LKKELSQKTLTKTSLEEIALHSSQISMDVNKSAQLLDILSRNEYPINKDARELLHSAPKE \\
\hline EIEC 144-7 & 50 & (1) \\
\hline EIEC 124-13 & 55 & ..D \\
\hline S.flexneri & 121 & AELDGDQMISHRELW AKIANSINDINEQYLKVYEHAVSSYTQMYQDFSAVLSSLAGWISP \\
\hline EIEC 144-7 & 110 & 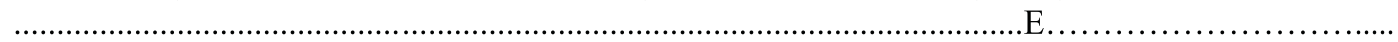 \\
\hline EIEC 124-13 & 115 & 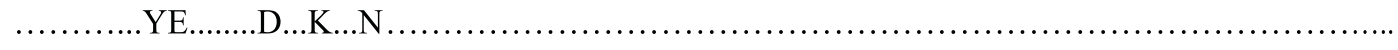 \\
\hline S.flexneri & 181 & GGNDGNSVKLQVNSLKKALEELKEKYKDKPLYP ANNTVSQEQANKWLTELGGTIGKVSQK \\
\hline EIEC 144-7 & 170 & . \\
\hline EIEC 124-13 & 175 & 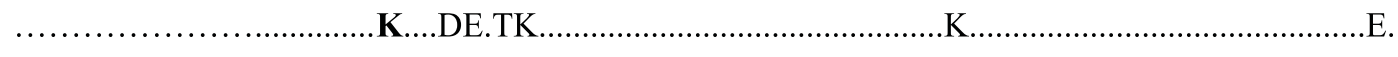 \\
\hline S.flexneri & 241 & NGGYVVSINMTPIDNMLKSLDNLGGNGEVVLDNAKYQAWNAGFSAEDETMK NNLQTLVQK \\
\hline EIEC 144-7 & 230 & 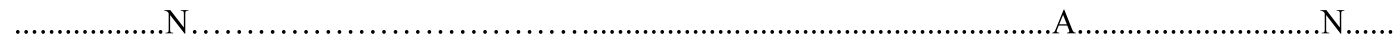 \\
\hline EIEC 124-13 & 235 & (. \\
\hline S.flexneri & 301 & YSNANSIFDNLVKVLSSTISSCTDTDKLFLHF \\
\hline EIEC 144-7 & 390 & 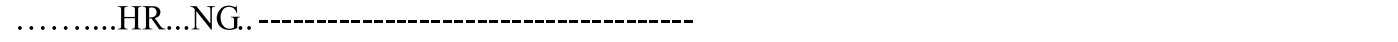 \\
\hline EIEC 124-13 & 395 & 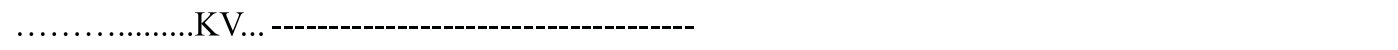 \\
\hline
\end{tabular}

Figure 3. Alignment of ipaD amino acid sequences of the S. flexneri, S. dysenteriae, and EIEC samples FBC144-7 (O144:NM) (without polymorphism) and FBC124-13 (O124:NM) (with polymorphism). The identical amino acids are indicated by dots. In the sample FBC124-13 a base change caused the amino acid change Asn (N) $\rightarrow$ Lys (K) (underlined).

The deduced amino acid sequence of IpaD with polymorphism showed a greater difference than the IpaB sequence of EIEC, when both were compared with S. flexneri M90T. The similarity between the FBC124-13 EIEC strain and $S$. flexneri M90T was $91 \%$ (Fig. 3), and 36\% when compared to SipD of Salmonella serovar Typhimurium $(4,10)$.

\section{DISCUSSION}

The interaction between facultative and obligate intracellular bacterial pathogens and host cells is a complex event that is accomplished by many different strategies (15). Shigella and EIEC are among a few bacteria which replicate freely in the cytoplasm of host cell. There are evidence that invasion plasmids of both bacteria hold high DNA homology, however, studies with EcoRV showed little similarity between profiles. $(6,18)$. This events might provoke differences in some gene expression

The molecular characterization of ipa $\mathrm{A}, i p a \mathrm{~B}, i p a \mathrm{C}$, and $i p a \mathrm{D}$ of EIEC has been done by PCR-RFLP assay, and the determination of $i p a \mathrm{~B}$ and $i p a \mathrm{D}$ nucleotide sequence. The amino-terminal and carboxyl-terminal regions of these genes show to be conserved, since ipa genes from nine EIEC serotypes were amplified by PCR assay using primer set designed from nucleotide sequence of Shigella ipa genes. All genes (ipaA, $i p a \mathrm{~B}$, ipa $\mathrm{C}$, and $i p a \mathrm{D})$ were amplified from all strains studied. The loss of one restriction site in EIEC IpaB sequence was due to the change of a single nucleotide. However, it is important to observe that this change is conserved in EIEC serotypes belonging to groups $\mathrm{B}$ and $\mathrm{C}$. Therefore, these differences are a molecular characteristic of these bacteria. The IpaB deduced amino acid sequences of FBC124-13 strain differed from those of FBC 0167-8 and Shigella strains by a small number of amino acids both in the amino-terminal and carboxyl-terminal regions.

The $S$. flexneri ipaB gene was divided into three regions, the amino-terminal, the carboxyl-terminal, and the middle region, which possesses two important domains ( $\alpha$-helix and hydrophobic). The amino-terminal region is very important for the expression and secretion of IpaB, while mutation in the carboxyl-terminal region do not affect these phenomena. Hydrophobic and $\alpha$-helix domains are crucial for the invasion and for the induction of macrophage death, since mutations in these regions led to the construction of non-virulent strains (4). When IpaB deduced amino acid sequences of S. flexneri 
M90T and FBC124-13 are compared, ten and seven different amino acids can be observed in the amino-terminal and carboxylterminal regions, respectively. However, the $\alpha$-helix and hydrophobic regions did not show differences in their nucleotide sequences. The importance of differences found in the aminoterminal region must be verified, since this region is crucial for the expression and secretion of IpaB (Guichon, et al., 2001). FBC124-13 was able to provoke guinea-pig keratoconjuntivitis only 5 days after the inoculum, while Shigella M90T did so after 24 hours, and FBC167-8, after 48 hours (data not shown).

The Ipa protein complex (IpaB-IpaD) has been proposed to occur in the outer membrane of Shigella and appears to play a role in modulating the transport of IpaC and IpaB (15). The IpaD carboxyl-terminal region may be involved in transport modulation, and the amino-terminal region would be involved in lysis and escape from host cell phagossomes (23). The deduced EIEC IpaD amino-acid sequence presented $91 \%$ of similarity with the Shigella strain. Amino acid changes occurred for whole protein structure, except in the carboxyl-terminal region, maybe because this region was not much exposed in the bacterial surface and selective environmental and immunological pressures could not contribute towards mutations (23).

Data shown here represent preliminary findings on the genetic differences between the EIEC and Shigella Ipa proteins. These differences are conserved among the EIEC serotypes and might influence bacterial pathogenicity. Further studies have to be carried out to elucidate whether the polymorphism presented for some EIEC serotypes may modify their pathogenicity.

The sequences described here have been assigned GenBank Accession numbers AY098990, AY098991, AY098992, and AF508305

\section{ACKNOWLEDGEMENTS}

This study was supported with grants from Fundação de Amparo à Pesquisa do Estado de São Paulo (FAPESP 00/050240), who also supported Carla R. Taddei. We thank the Conselho Nacional de Desenvolvimento Científico e Tecnológico (CNPq) for granting Adriana Gibotti and Tania L. Tanaka fellowships. We are indebted to Dr. Carlos F. M. Menck for helping us with the nucleotide sequences and to Dr Waldir P Elias Jr for his technical suggestions.

\section{RESUMO}

\section{Caracterização molecular do gene ipa de Escherichia coli enteroinvasora pela análise de PCR- RFLP}

No presente estudo, foi encontrado polimorfismo no gene ipa em cinco sorotipos de EIEC, de nove estudados. Quando enzimas de restrição SalI e HindII foram utilizadas no ensaio de PCR-RFLP, amostras de EIEC apresentaram polimorfismo em $i p a \mathrm{~B}$ e ipa $\mathrm{D}$. Por outro lado, não foram observados polimorfismos nos genes ipa $\mathrm{A}$ e ipa $\mathrm{C}$ nestas cepas, quando diversas enzimas de restrição foram utilizadas. O polimorfismo presente em cepas de EIEC é sorotipo-dependente, uma vez que os padrões de restrição foram conservados entre as cepas pertencentes ao mesmo sorotipo. Quando a seqüência deduzida de aminoácidos de IpaB de S. flexneri M90T e FBC124-13 foram comparadas, mudanças foram observadas em dez aminoácidos na região amino-terminal. A seqüência deduzida de aminoácidos de IpaD de EIEC apresentou similaridade de $91 \%$ com a cepa de Shigella. Neste caso, mudanças de aminoácidos ocorreram em toda a estrutura da molécula de IpaD, exceto na região carboxiterminal.

Palavras-chave: ipa, Escherichia coli enteroinvasora, polimorfismo, PCR-RFLP

\section{REFERENCES}

1. Almeida, M.T.G.; Silva, R.M.; Donaire, L.M.; Moreira, L.E.; Martinez, M.B. Enteropatógenos associados com diarréia aguda em crianças. J. Pediatria, Rio de Janeiro. 74: 291-298, 1998.

2. Echeverria, P.; Sethabutr, O.; Serichantalergs, O.; Lexomboon, U.; Tamura, K. Shigella and enteroinvasive Escherichia coli infections in households of children with dysentery in Bangkok. J. Infect. Dis., 165: 144-147, 1992.

3. Ewing, W.H. Edwards and Ewing's identification of Enterobacteriacae. 4th Edn., p.135-172. Elsevier Science, New York, NY, 1986.

4. Guichon, A.; Hersh, D.; Smith, M.R.; Zychlinsky, A. Structurefunction analysis of the Shigella virulence factor IpaB. J. Bacteriol. 183: 1269-1276, 2001.

5. Hale, T.L. Bacillary dysentery. In Topley and Wilson's Microbiology and Microbiol Infections. Vol. 3. Hansler, W.J., and Shuman, M. (eds). London: Arnold, pp. 479-493, 1998.

6. Hale, T.L.; Sansonetti, P.J.; Schad, P.A.; Austin, S.; Formal, S.B. Characterization of virulence plasmids and plasmid - associated outer membrane proteins of Shigella flexneri, Shigella sonnei and Escherichia coli. Infect. Immun., 40: 340-350, 1983.

7. Harris, J.R.; Wachsmuth, I.K.; Davis, B.R.; Cohen, M.L. Highmolecular-weight plasmid correlates with Escherichia coli enteroinvasiveness. Infect. Immun., 37: 1295-1298, 1982.

8. High, N.; Mounier, J.; Prévost, M.C.; Sansonett, P.J. IpaB of Shigella flexneri causes entry into epithelial cells and escape from the phagocytic vacuole. EMBO J., 11: 1991-1999, 1992.

9. Kain, K.C.; Barteluk, R.L.; Kelly, M.T.; Xin, H.; De Hua, G.; Yuan, G.; Proctor, E.M.; Byrne, S.; Stiver, H.G. Etiology of childhood diarrhea in Beijing China. J. Clin. Microbiol., 29: 90-95, 1991.

10. Kaniga, K.; Tucke, S.; Trollinger, D.; Galan, J.E. Homologs of the Shigella IpaB and IpaC invasins are required for Salmonella typhimurium entry into cultured epithelial cells. J. Bacteriol., 177: 3965-3971, 1995.

11. Martinez, M.B.; Whittan, T.S.; McGraw, E.A.; Rodrigues, J.; Trabulsi, L.R. Clonal relationship among invasive and non-invasive strains of enteroinvasive Escherichia coli serogroups. FEMS Microbiol. Lett., 172(2): 145-51, 1999.

12. Ménard, R.; Dehio, C.; Sansonetti, P.J. Bacterial entry into epithelial cells: the paradigm of Shigella. Trends in Microbiol., 4: 220-226, 1996. 
13. Nataro, J.P.; Kaper, J.B. Diarrheagenic Escherichia coli. Clin. Microbiol. Rev., 11: 142-201, 1998.

14. Ogunsanya, T.I.; Rotimi, V.O.; Adenuga, A. A study of aetiological agents of childhood diarrhoea in Lagos, Nigeria. J. Med. Microbiol., 40: 10-14, 1994.

15. Parsot, C.; Sansoneti, P.J. Invasion and pathogenesis of Shigella infections. In: Miller, V.L. (ed.) Bacterial Invasiveness. Cur. Trop. Microbiol. Immunol., 25-42, 1996.

16. Prats, G.; Llovet, T. Enteroinvasive Escherichia coli: Pathogenic mechanisms and epidemiology. Microbiologia., 11: 91-96, 1995.

17. Sakazaki, R.; Tamura, K.; Saito, M. Enteropathogenic Escherichia coli associated with diarrhea in children and adults. Jap. J. Med. Sci. Biol., 20: 387-399, 1967.

18. Sansonetti, P.J.; Kopecko, D.; Formal, S.B. Involvement of a plasmid in the invasive ability of Shigella flexneri. Infect. Immun., 35: 852$860,1982$.

19. Séreny, B. Biochemical reactions and virulence of Escherichia coli O124, K72 (B17). Acta Microbiol. Acad. Sci. Hung., 10: 11-18, 1963.
20. Tamura, K.; Sakazaki, R.; Murase, M.; Kosako, Y. Serotyping and categorisation of Escherichia coli strains isolated between 1958 and 1992 from diarrhoeal diseses in Asia. J. Med. Microbiol., 45:353358, 1996.

21. Toledo, M.R.F.; Trabulsi, L.R. Frequency of enteroinvasive Escherichia coli in children with diarrhea and healthy controls, in São Paulo, SP, Brazil. Rev. Microbiol., 21: 1-4, 1990.

22. Trabulsi, L.R.; Fernandes, M.R.; Zuliani, M.E. Novas bactérias patogênicas para o intestino do homem. Rev. Inst. Med. Trop., 9: 3139, 1967.

23. Turbyfill, K.R.; Mertz, J.A.; Mallett, C.P.; Oaks, E.V. Identification of epitope and surface - exposed domains of Shigella flexneri invasion plasmid antigen D (IpaD). Infect. Immun., 66: 1999-2006, 1998.

24. Venkatesan, M.M.; Goldberg, M.B.; Rose, D.J., Grotbeck, E.J.; Burland V.; Blattener, F.R. Complete DNA sequence and analysis of the large virulence plasmid of Shigella flexneri. Infect. Immun., 69: 32713285, 2001.

25. Zychlinsky, A.M.; Prévot, M.C.; Sansonetti, P.J. Shigella flexneri induces apoptosis in infected macrophages. Nature, 358: 167-168, 1992. 